\title{
Management of a university ambulatory service: nursing in the coping of the pandemic of COVID-19
}

\author{
Gestão de um serviço ambulatorial universitário: a enfermagem no enfrentamento da pandemia de COVID-19 \\ Gestión de un servicio ambulatorio universitario: enfermería en la coping de la pandemia de COVID-19
}

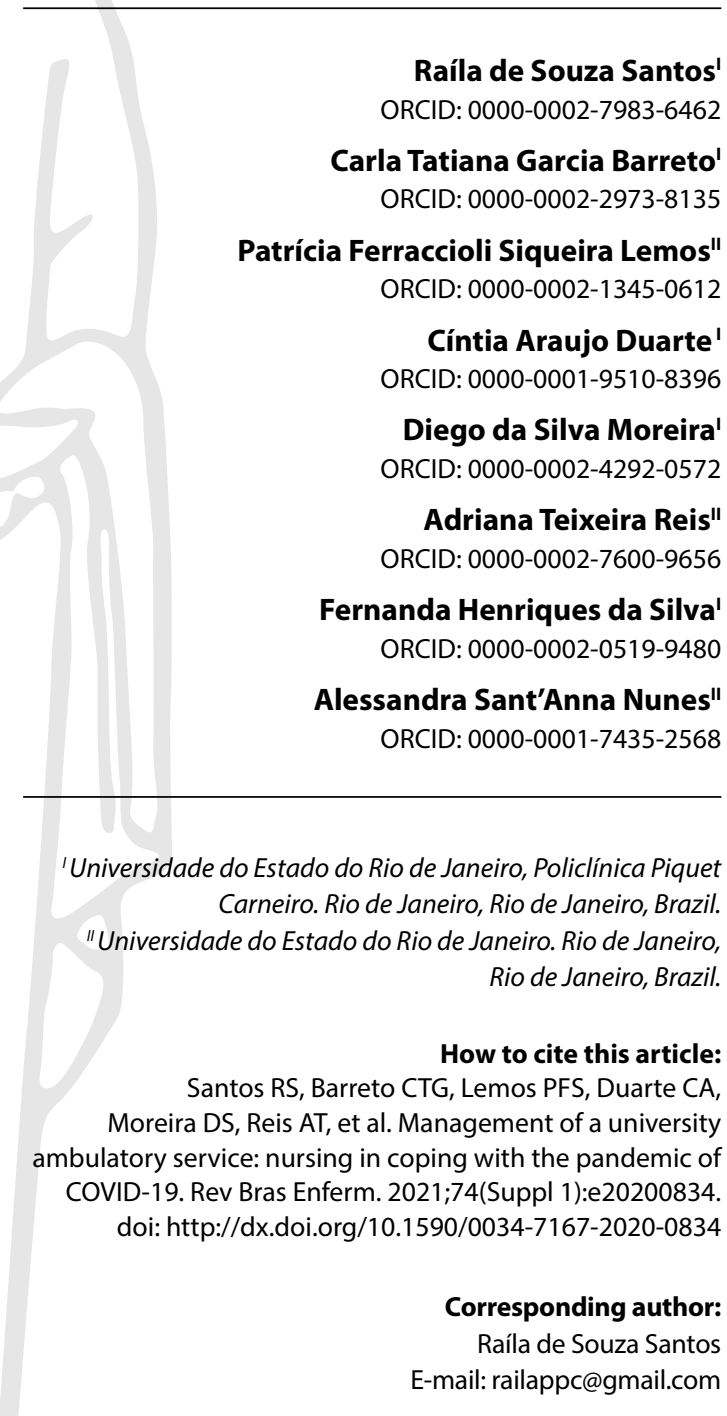

EDITOR IN CHIEF: Dulce Barbosa ASSOCIATE EDITOR: Alexandre Balsanelli

\begin{abstract}
Objective: to describe the implementation and management of a restructured nursing service to cope with the COVID-19 pandemic. Methods: a descriptive study, carried out at Piquet Carneiro Polyclinic, a university ambulatory unit, which became a reference for testing the severe acute respiratory syndrome coronavirus 2 (SARS-CoV-2) in the city of Rio de Janeiro. Results: dimensioning of human resources for nursing was carried out; flows for serving users of the unit and for testing SARS-CoV-2; professional training on prevention practices. From March 18 to July 3, a total of 31214 services were made by the nursing team, 25424 for testing and 453 health professionals received professional training. Final considerations: nursing represents an important workforce, planning and management for restructuring health services in an emergency, due to its broad managerial, educative and direct care to the population.

Descriptors: Nursing; Health Services Administration; Inservice Training; Pandemics; Coronavirus Infections.
\end{abstract}

\section{RESUMO}

Objetivo: descrever a implementação e gestão de um serviço de enfermagem reestruturado para o enfrentamento da pandemia de COVID-19. Métodos: estudo descritivo, desenvolvido na Policlínica Piquet Carneiro, unidade ambulatorial universitária, que se tornou referência para testagem do coronavírus, da síndrome respiratória aguda grave 2 (SARS-CoV-2), localizada no município do Rio de Janeiro. Resultados: foi realizado dimensionamento dos recursos humanos da enfermagem; fluxos para atendimento dos usuários da unidade e para testagem de SARS-COV-2; treinamento profissional sobre práticas de prevenção. No período de 18 de março a 3 de julho, 31.214 atendimentos foram feitos pela equipe de enfermagem, sendo 25.424 para testagem e 453 profissionais de saúde receberam treinamento profissional. Considerações finais: a enfermagem representa uma força de trabalho, de planejamento e de gestão importante para reestruturação dos serviços de saúde em caráter emergencial, visto sua ampla visão gerencial, educadora e de assistência direta à população.

Descritores: Enfermagem; Administração de Serviços de Saúde; Capacitação em Serviço; Pandemias; Infecções por Coronavírus.

\section{RESUMEN}

Objetivo: describir la aplicación y la gestión de un servicio de enfermería reestructurado para el afrontamiento de la pandemia de COVID-19. Métodos: se trata de un estudio descriptivo desarrollado en la Policlínica Piquet Carneiro, unidad ambulatoria universitaria de la ciudad de Río de Janeiro, que se convirtió en referencia para el testeo del coronavirus, síndrome respiratorio agudo severo 2 (SARS-CoV-2). Resultados: se dimensionaron los recursos humanos de enfermería, los flujos para atender a los usuarios de la unidad y para testear el SARS-COV-2 y la capacitación profesional en prácticas de prevención. Del 18 de marzo al 3 de julio, el equipo de enfermería prestó 31.214 servicios, de los cuales 25.424 fueron testeos y se impartió formación profesional a 453 profesionales de la salud. Consideraciones finales: la enfermería representa una importante fuerza de trabajo, planificación y gestión para la reestructuración de los servicios de salud en una emergencia, dada su amplia visión gerencial, educativa y de asistencia directa a la población.

Descriptores: Enfermería; Administración de los Servicios de Salud; Capacitación en Servicio; Pandemias; Infecciones por Coronavirus. 


\section{INTRODUCTION}

Since the beginning of the current declaration of a worldwide pandemic by the new Coronavirus (SARS-CoV 2), which caused COVID-19, there has been great concern in the face of a disease that has spread rapidly in several regions of the world with devastating impacts in Brazil and worldwide. Data from the World Health Organization (WHO) show more than 10 million cases and almost 500 thousand deaths worldwide until June $2020^{(1)}$.

Currently, Brazil is considered the new epicenter of the pandemic, accounting for more than 1 million confirmed cases and around 80 thousand deaths. According to the Ministry of Health, the southeastern region of the country is the most affected, and the state of Rio de Janeiro has the highest mortality rate due to COVID-19 (31.6 per 100 thousand inhabitants) ${ }^{(2-3)}$.

As it is a new disease that has spread rapidly in several regions of the world, there were no strategic plans ready to be applied. The existing recommendations of national and international organizations suggest the application of Influenza contingency plans, due to the clinical and epidemiological similarities between these respiratory viruses ${ }^{(4-6)}$. Therefore, with this scenario of uncertainty, the pandemic of COVID-19 had a great impact on the performance of health professionals and managers at different levels of health care.

Thus, the Piquet Carneiro Polyclinic, which belongs to the State University of Rio de Janeiro (UERJ), developed in record time an ambulatory flow to provide immediate support in the diagnosis of COVID-19, aiming to avoid the collapse of the network in the face of the increase the volume of visits in search of diagnosis and also due to the lack of tests and specific testing centers in the state of RJ.

This new context of care to cope with the pandemic demanded the reorganization of care for users undergoing treatment at the institution, resizing of the work team in the face of the new demand for care, readjustment of physical space, organization and purchase of material, in addition to intense training routines with focus on the safety of professionals and the proper use of Personal Protective Equipment (PPE). It is noteworthy in this study the flow elaborated and performed by nursing for the classification of risk and screening of users of the unit, as well as symptomatic health professionals who started to be attended at the institution due to the pandemic of COVID-19.

Therefore, considering the gaps in the literature on the implementation of contingency plans for organizing services in emergency contexts, as well as pandemics, this study is essential and can be a guide for other health services.

\section{OBJECTIVE}

To describe the implementation and management of a nursing service, in the university ambulatory context, restructured to cope with the COVID-19 pandemic.

\section{METHODS}

\section{Ethical aspects}

This study followed the ethical precepts of research with human beings and was approved by the Research Ethics Committee responsible for the study.

\section{Type of study}

Descriptive study, which enabled a detailed analysis of the implementation of a restructured ambulatory nursing service to cope with the COVID-19 pandemic.

\section{Study scenario}

The development scenario for this study was the Piquet Carneiro Polyclinic, a specialized care unit that corresponds to one of the ambulatory components of the UERJ health complex.

\section{Data collection}

The data collection period started concomitantly with the implementation of the service reorganization, from March 18th to July 3rd, 2020. Data were collected from the implementation and readjustment protocols of service flows, management of human and material resources; as well as training focused on the safety of professionals to cope with the COVID-19 pandemic.

\section{Methodological procedures}

For the production of service flows and training programs, steps that encompass situational diagnosis, implementation, evaluation of results and production of knowledge were adopted.

The situational diagnosis included the delimitation of structural, human and material resources; contact with nursing professionals; the team sizing for the service restructuring; the participants' self-training process.

In the implementation stage, the profile of users served after restructuring was defined. In addition to discussing the different topics that involved the construction of flows and the distribution of the service and disseminating actions concerning service and possibilities for alternatives for discussion and analysis.

The evaluation stage included the continuation of discussions about the themes that involved care and the construction of flows; process of decoding the meetings; proposals, evaluation and continuous updating of the proposed flows.

Finally, the knowledge production and learning stage covered the selection of ideas and planning of educational actions and training; the production and dissemination of educational training material through digital and printed material; a final assessment of the entire process.

\section{RESULTS}

\section{Profile of appointments at the Piquet Carneiro Polyclinic}

The service profile at Piquet Carneiro Polyclinic includes a predominantly older adult patients with comorbidities in different specialties in chronic non-communicable diseases (NCDs). During the COVID-19 pandemic, a contingency plan was drawn up with new flows of care in order to reduce the possibility of spreading SARS-CoV 2 within the unit between professionals and users. For this moment, the institution's general management organized an external physical space in the unit parking lot with tents and refrigerated containers, in order to attend to suspected cases of flu syndrome (FS) (Figure 1). 


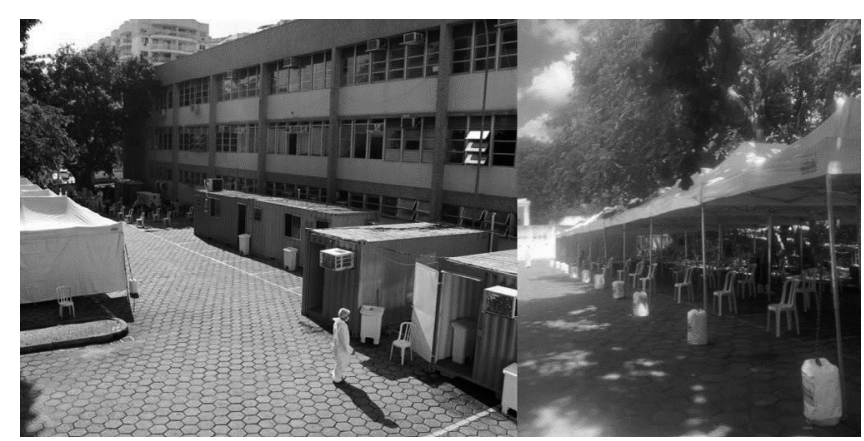

Figure 1 - External physical space to care for suspected cases of flu syndrome in the Piquet Carneiro Polyclinic

Concomitant with the reorganization of care for users undergoing treatment at the Polyclinic, testing for SARS-CoV-2 was implemented, which was initially performed for health professionals with FS symptoms in the UERJ health complex. However, with the exponential increase in cases, this service has been expanded to health and public safety professionals in the entire metropolitan region of Rio de Janeiro.

The nursing team of the Polyclinic was organized into two care flows, both contemplating FS assessment. The first flow was for screening and risk classification of users with NCDs previously accompanied by the Polyclinic specialties and who could not have their treatment postponed. On the other hand, the second flow was for the risk classification of symptomatic health professionals who sought the service for testing SARS-CoV-2.

\section{Team sizing}

From the beginning of the contingency plan, the work of dimensioning the nursing team at Piquet Carneiro Polyclinic prioritized the immediate removal from the face-to-face work activities of all professionals who belonged to the risk group established by the Department of Safety and Health at Work (Dessaude) of UERJ ${ }^{(7)}$. In the nursing team, a total of 8 employees aged 60 years old or older, 5 employees with decompensated chronic diseases and 1 pregnant woman were removed. A second evaluation was carried out by the nursing supervision, considering professionals with a high degree of stress and other situations, who were allocated to management activities, organization and dispensing of materials, support and care in areas where suspected cases of COVID-19 were not attended to.

Professionals who did not fit the cases previously reported were assigned to act on the front line of screening and risk classification for testing suspected cases of COVID-19. The daily composition of the front-line nursing team was approximately a total of 12 nursing technicians for screening, 4 nurses for risk classification and 3 supervising nurses. The service was developed in an open space, in the institution parking lot, and in a non-air-conditioned environment. The professionals used the following PPE: waterproof coveralls, glasses, cap, N95 mask and procedure gloves. Two daily shifts were implemented, each professional spent a maximum of 5 hours dressed, to reduce the professional's exposure time and minimize the stress and discomfort caused by the use of PPE outdoors.

It was necessary to introduce internal tracking to identify suspicious cases among symptomatic professionals in the workforce or who would have symptomatic domestic contacts. When any health team professional had suspicious symptoms, they were immediately removed from activities and referred for the Polymerase Chain Reaction-Reverse Transcriptase (RT-PCR) test, considered the gold standard for detecting SARS-CoV-2, if positive was removed for initially 14 days. Between March 11 and June 20, a total of 12 nurses and 39 nursing technicians were registered on suspicion of COVID 19. Among nurses, 6 had a positive diagnosis for SARSCoV-2 and among nursing technicians, 19 were positive and 3 were inconclusive for SARS-CoV-2. The number of cases of positive professionals compared to the universe of the team was $19.4 \%$ of nurses and $23.8 \%$ of nursing technicians, no nursing professional on the team evolved to hospitalization or death.

\section{Flow for serving users with non-communicable diseases and for testing SARS-COV-2}

A week after the first confirmed case of COVID-19 in the state of Rio de Janeiro, the service reorganization project started to be carried out. The first step was to outline strategies for reorganizing users' appointments, either scheduled or due to spontaneous demand, to update revenue among other needs related to the treatment of NCDs.

First, the user was screened by the nursing technician who filled out the identification form, checked temperature, respiratory rate, oxygen saturation and applied a questionnaire to identify FS. The team of nursing technicians also referred cases with vital signs outside the reference standards and identified, in the waiting list, the priorities for care with nurses. In the absence of FS and normal vital signs, users were identified with a white bracelet and allowed to enter the institution for their ambulatory consultation or examination (Figure 2).

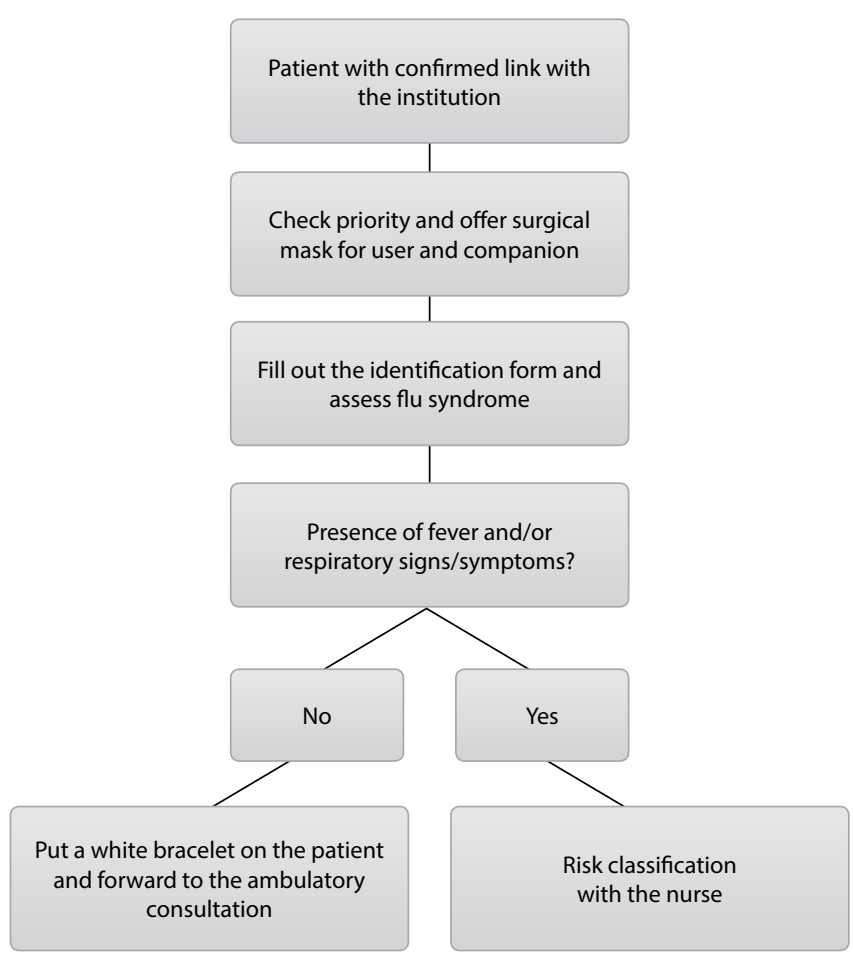

Figure 2 - Flowchart of service for users, scheduled or spontaneously demanded, for the treatment of chronic diseases 
In case of suspicion, the user was referred to the nurse professional, to carry out the risk classification and test for SARS-CoV-2. It should be noted that nursing technicians were trained to work in this flow of care and the team was supervised by two nurses on a daily basis, so that doubts could be clarified.

With the growth of cases in the city, the Polyclinic was consolidated as a reference for testing health professionals with suspected COVID-19. The number of visits was approximately 70 per day in March, initially for an internal group of the UERJ health complex. However, due to the increased demand for suspected health professionals for testing, an online appointment was organized, in which the average attendance increased to around 700 attendances/day in the months of April, May and June.

For testing, there was a nurse professional who was responsible for the risk classification in relation to health professionals suspected of contracting COVID-19. The attendance with nurses contemplated guidelines on social isolation, the correct period to perform the RT-PCR or Rapid Test and clinical evaluation. All care was recorded on a form, in which the clinical picture of FS was identified, the date of the onset of symptoms for classification of the test to be performed (RT-PCR or rapid serological test) and indication for medical consultation (Figure 3).

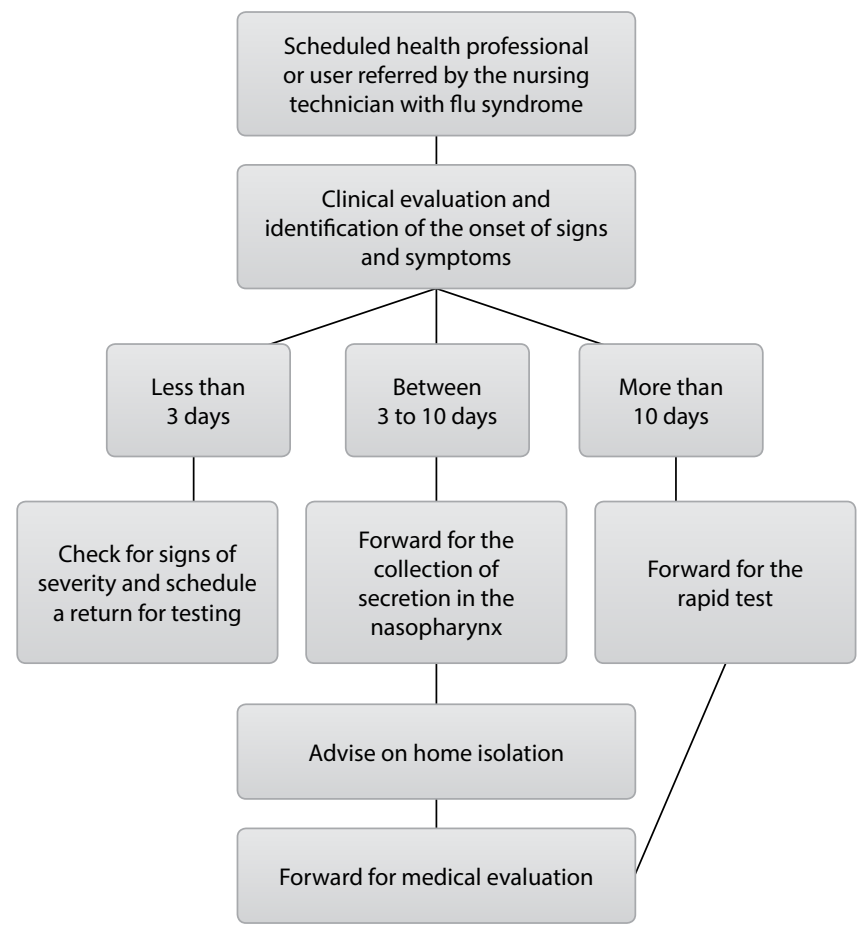

Figure 3 - Flowchart of suspicious case care for testing the new coronavirus (Sars-CoV-2)
The changes in flow followed strategic steps and started from the principle of continuous improvement based on constant changes, according to new scientific publications and recommendations from WHO and the Ministry of Health, in order to provide better care and safety for the professionals involved and users served.

From March 18 to July 3, a total of 31214 visits were made by the team, of which 5790 were attended by users of the unit. Of the total number of consultations, 25424 were referred for SARS-CoV-2 testing.

\section{Knowledge production and learning}

The first professional training at the institution was held on March 18, 2020. Chart 1 describes all the topics addressed during the training, established from a script with objective, program content, teaching methodology and material resources. The entire structure was based on active methodologies, in order to allow teachers and nurses to insert themselves in this context and conduct training for other health professionals.

Initially, priority was given to health professionals from the institution, mainly professionals who would work on the front line. In addition to these, specific training was also carried out with hygiene and cleaning professionals on hand hygiene, surface disinfection and PPE dressing, through the conversation wheel dynamics, in order to raise awareness and instruct on the importance and proper use of PPE (Chart 1).

After this first stage of internal training and with the advance of the pandemic, there was a need to train more health professionals to work at that moment. The training was published on the Polyclinic official website, through registration via online form, allowing the training of health professionals from all UERJ and external professionals. Thus, it was consolidated as a reference training for health professionals and an opportunity for institutions that were not able to train their teams.

There was also an increase in the demand for students (academics, interns and residents) from various areas who were interested in carrying out the training. However, the training for this group was structured differently, in order to guarantee, in addition to the practical content, other content relevant to the training and performance of students. To assess the impact of training for the professionals involved and to foster a critical review of this process, an online questionnaire was prepared to assess training through the QR code system. This strategy aimed to obtain the characterization data of the professionals and the training with the subsequent objective of evaluating the satisfaction and quality of the training (Chart 1).

Chart 1 - Description of the topics addressed during professional training at the Piquet Carneiro Polyclinic

\begin{tabular}{|l|}
\hline TRAINING FOR HEALTH PROFESSIONALS IN CARE OF CORONAVIRUS (COVID-19) SUSPECTED/CONFIRMED CASES IN THE AMBULATORY \\
ENVIRONMENT \\
\hline DURATION: 50 min \\
TARGET PUBLIC: Health professionals and students \\
SETTING: Piquet Carneiro Polyclinic \\
OBJECTIVE: promote the development of the safety capacity of health professionals during care, through the correct, safe and rational use of PPE in \\
health services with care for COVID-19
\end{tabular}

To be continued 


\begin{tabular}{|c|c|c|c|}
\hline OBJECTIVE & PROGRAM CONTENT & ACTIVITY & MATERIAL RESOURCES \\
\hline $\begin{array}{l}\text { To know the origin and category of } \\
\text { participating health professionals }\end{array}$ & $\begin{array}{l}\text { Brief presentation of the work origin and } \\
\text { the category of each participant }\end{array}$ & -Presentation & $\begin{array}{l}\text {-A4 clipboard. } \\
\text { - Attendance list }\end{array}$ \\
\hline $\begin{array}{l}\text { To discuss the characteristics of } \\
\text { the SARS COV-2 virus and the } \\
\text { COVID-19 disease }\end{array}$ & $\begin{array}{l}\text { Coronavirus, Covid- } 19 \text { (definition, } \\
\text { characteristics, types of virus } \\
\text { transmission) }\end{array}$ & -Dialogue exhibition & - \\
\hline $\begin{array}{l}\text { To review the hand hygiene } \\
\text { technique with } 70 \% \text { alcoholic } \\
\text { solution and surface disinfection } \\
\text { methods }\end{array}$ & $\begin{array}{l}\text { Hand hygiene, antisepsis with } 70 \% \\
\text { alcohol and disinfection of materials and } \\
\text { surfaces }\end{array}$ & $\begin{array}{l}\text {-Dialogue exhibition } \\
\text {-Practical demonstration of the } \\
\text { antiseptic hand-wicking technique } \\
\text { with } 70 \% \text { alcohol preparation }\end{array}$ & $\begin{array}{l}\text {-Sprayer with } 70 \% \\
\text { alcohol preparation }\end{array}$ \\
\hline \multirow{4}{*}{$\begin{array}{l}\text { To sensitize health professionals } \\
\text { about the need for the correct, } \\
\text { safe and rational use of PPEs, } \\
\text { in different scenarios in the } \\
\text { prevention of exposure to } \\
\text { COVID-19 }\end{array}$} & $\begin{array}{l}\text { Care in the professional environment } \\
\text { (clothing, ornaments, nail care) }\end{array}$ & -Dialogue exhibition & - \\
\hline & $\begin{array}{l}\text { PPE (adequate information, cost, } \\
\text { expiration date, durability, conservation, } \\
\text { manufacturer's information, importance } \\
\text { of rationalizing the use of PPE, proper } \\
\text { room for dressing/undressing) }\end{array}$ & \multirow{3}{*}{-Dialogue exhibition } & - \\
\hline & $\begin{array}{l}\text { Reflection on the use of PPE in different } \\
\text { environments according to precautionary } \\
\text { needs (pattern, contact, droplet or aerosol) }\end{array}$ & & - \\
\hline & $\begin{array}{l}\text { Constant updating of rules, ordinances, } \\
\text { legislation from safe sources, in addition } \\
\text { to combating fake news }\end{array}$ & & - \\
\hline $\begin{array}{l}\text { To discuss appropriate care in the } \\
\text { home environment }\end{array}$ & $\begin{array}{l}\text { How to prevent the spread of Covid-19 in } \\
\text { the home environment }\end{array}$ & -Dialogue exhibition & - \\
\hline $\begin{array}{l}\text { To present the service flow of PPC, } \\
\text { in the context of COVID- } 19\end{array}$ & $\begin{array}{l}\text { Current Context of the PPC (specialized } \\
\text { unit, essential services, reference center, } \\
\text { service, flow, screening and classification } \\
\text { of users and health professionals) }\end{array}$ & -Dialogue exhibition & - \\
\hline $\begin{array}{l}\text { To simulate the stages of the } \\
\text { dressing process and the safe, } \\
\text { adequate and rational positioning } \\
\text { of PPE for environments with } \\
\text { aerosol precautions }\end{array}$ & $\begin{array}{l}\text { Demonstration of the stages of the } \\
\text { dressing process and proper use of PPEs }\end{array}$ & $\begin{array}{l}\text {-Dialogue exhibition } \\
\text {-Simulation with practical } \\
\text { demonstration of the dressing } \\
\text { technique } \\
\text {-Observation and clarification of doubts }\end{array}$ & \multirow{2}{*}{$\begin{array}{l}\text {-Waterproof coveralls; } \\
\text {-Mask N95; } \\
\text {-Cap; } \\
\text {-Glasses; } \\
\text {-Face Shields; } \\
\text {-Procedure gloves; } \\
\text {-70\% alcoholic solution; } \\
\text {-Paper towel; } \\
\text {-Infective waste bin; } \\
\text {-Waste bin for common } \\
\text { waste. }\end{array}$} \\
\hline $\begin{array}{l}\text { To simulate the steps for the } \\
\text { removal process and the } \\
\text { appropriate technique to avoid } \\
\text { contamination }\end{array}$ & $\begin{array}{l}\text { Demonstration of the stages of the } \\
\text { undressing process and proper use of PPE }\end{array}$ & $\begin{array}{l}\text {-Dialogue exhibition } \\
\text {-Simulation with practical } \\
\text { demonstration of the unbundling } \\
\text { technique } \\
\text {-Observation and clarification of doubts }\end{array}$ & \\
\hline $\begin{array}{l}\text { To evaluate training using a remote } \\
\text { questionnaire (QR Code) }\end{array}$ & $\begin{array}{l}\text { Evaluation through online questionnaire } \\
\text { (QR Code) }\end{array}$ & -Remote evaluation & $\begin{array}{l}\text {-Mobile device (cell phone) } \\
\text { with internet access }\end{array}$ \\
\hline
\end{tabular}

In total, 453 health professionals underwent training, such as nurses, nursing technicians, cleaning staff, clinical analysis technician, radiology, social worker, physiotherapists and doctors; in addition to medical students, nursing students (nursing residents, academics, interns and medical residents) and other volunteers. At the end, all the training developed was transformed into technical production at the unit.

\section{DISCUSSION}

This study showed that even in an emergency scenario, it is possible to plan service flows, manage human and material resources and adopt conducts to prepare the team and provide protection and prevention training. Such behaviors were extremely relevant to the development of work and protection of the nursing team in coping with the pandemic. It is important to consider that the collective planning of care flows to cope with adverse situations such as pandemics, catastrophes and others, alleviates psychological suffering and losses to health professionals and the assisted population ${ }^{(8-9)}$.
According to a study on coping with the emerging MERS-CoV disease, half of the professionals reported that their job performance decreased while they suspected they had contracted the disease, almost two-thirds reported anxiety in attending to suspected cases and had psychological problems during the epi$\operatorname{demic}^{(8)}$. Another study that developed an educational program led by nurses to screen and screen patients with MERS-CoV infection showed that the application of specific protocols minimized the risks of cross-infection, prioritizing the safety of users and team, in addition to providing more effective and standardized care ${ }^{(10)}$.

It is important to highlight that the professionals at the Piquet Carneiro Polyclinic had a routine of care, prior to the pandemic focused on NCDs, reinforcing the need to update knowledge on measures for the prevention and control of communicable diseases. A pattern also observed by a study conducted in the Middle East, showing that knowledge about emerging infectious diseases and infection control practices was very low among health professionals, confirming the need for education and training programs, particularly in the use of PPE, isolation and infection control measures. 
Thus, our training teaching planning included the use of PPE, hand hygiene, placement and adjustment of surgical mask and N95 and the practice of dressing and removing PPE, which are essential topics for front-line health professionals ${ }^{(11-14)}$. In addition, another relevant factor observed in PPE training was the need for work focused on psychological security through a second training to provide feedback on experiences in practice, as suggested by other teaching strategies ${ }^{(11,13-14)}$.

The reality of most health institutions in Brazil and in the world shows the difficulties faced related to the shortage of PPE. Among all the challenges encountered, are the increase in prices associated with the shortage of the market and the dependence on the industry in China that produces a large part of the PPE used in Brazil(15). However, Piquet Carneiro Polyclinic endeavored to guarantee PPE, most health professionals attended for testing recognized how well equipped the team was and reported the lack of PPE in their home institutions.

\section{Limitations of the study}

As limitations, despite all the efforts and infection control strategies aimed at professionals, with the time of work the number of suspected cases began to increase among the team, since many professionals have a double work relationship, increasing exposure to the virus. At this time, as adopted in other studies, internal screening strategies were necessary to identify symptomatic and asymptomatic cases among the workforce ${ }^{(16-17)}$. Another limitation is the lack of comparability with other studies due to the limited number of publications on a topic as recent as the COVID-19 pandemic.

\section{Contributions to the area}

Among the potentialities are the dissemination of emergency management actions to deal with the pandemic on an ambulatory basis, so that services of the same nature can guide actions capable of achieving positive results in coping with the pandemic. In addition, the study highlights the instrumental potentialities that nursing has to implement and manage actions, protocols and flows of care with an emphasis on patient care and safety, as well as for training the team of health professionals in the area of nursing in coping with emerging diseases, as in the current COVID-19 pandemic.

\section{FINAL CONSIDERATIONS}

The pandemic is still ongoing and there is a lot of progress to be made in the knowledge about COVID-19, so it is essential to invest in actions that contemplate the improvement of working environments and conditions for front-line health professionals, who are exposed to high stress loads and impacts on their physical and mental health. Therefore, the expansion and dissemination of contingency plans to face emergency situations is essential and serves as reference for other services.

Therefore, the emergency management actions described in this study to cope with the COVID-19 pandemic allow us to show that nursing represents an important planning, management and work force for the organization of health services, due to its broad managerial, educative and direct care to the population.

\section{ACKNOWLEDGMENT}

To the colleagues of the Polyclinic Piquet Carneiro who worked tirelessly during the pandemic and guaranteed quality and safety assistance to the population.

The nursing team, for all its dedication, professionalism and responsibility.

The Faculty of Nursing that was present at all times, especially professors who worked directly with the training of the polyclinic team.

\section{REFERENCES}

1. World Health Organization (WHO). Coronavirus disease (COVID-19)[Internet]. 2020 [cited 2020 Jul 13]. Available from: https://www.who.int/ docs/default-source/coronaviruse/situation-reports/20200629-covid-19-sitrep-161.pdf?sfvrsn=74fde64e_2

2. Ministério da Saúde (BR). Boletim epidemiológico: doença pelo coronavírus COVID-19. Semana Epidemiológica 28 (05 a 11/07) [Internet]. 2020 [cited 2020 Jun 5]. Available from: https://www.saude.gov.br/images/pdf/2020/July/15/Boletim-epidemiologico-COVID-22.pdf

3. Ministério da Saúde (BR). Guia de vigilância epidemiológica: emergência de saúde pública de importância nacional pela doença pelo Coronavírus 2019 [Internet]. 2020 [cited 2020 Jun 5]. Available from: http://docs.bvsalud.org/biblioref/2020/05/1096732/guiadevigiepidemc19-v2.pdf

4. Freitas ARR, Napimoga M, Donalisio MR. Análise da gravidade da pandemia de Covid-19. Epidemiol Serv Saúde. 2020;29(2). https://doi. org/10.5123/S1679-49742020000200008

5. Ornell F, Schuch JB, Sordi AO, Kessler FHP. "Pandemic fear” and COVID-19: mental health burden and strategies. Braz J Psychiatry. 2020;42(3). https://doi.org/10.1590/1516-4446-2020-0008

6. Werneck GL, Carvalho MS. A pandemia de COVID-19 no Brasil: crônica de uma crise sanitária anunciada. Cad Saúde Pública. 2020;36(5). https://doi.org/10.1590/0102-311x00068820

7. Universidade do Estado do Rio de Janeiro. Ato Executivo de Decisão Administrativa (AEDA-013/2020). [Internet]. 2020 [cited 2020 Apr 12]. Available from: https://www.uerj.br/wp-content/uploads/2020/03/AEDA-013.pdf

8. Alsahafi A, Cheng A. Knowledge, attitudes and behaviours of healthcare workers in the Kingdom of Saudi Arabia to MERS Coronavirus and other emerging infectious diseases. Int J Environ Res Public Health. 2016;13(12):1214. https://doi.org/10.3390/ijerph13121214

9. Meneses AS. Gerenciamento emergencial de recursos da atenção primária à saúde no enfrentamento à pandemia da COVID-19. 2020 . https://doi.org/10.1590/SciELOPreprints.557 
10. Al-Tawfiq JA, Rothwell S, Mcgregor HA, Khouri ZA. A multi-faceted approach of a nursing led education in response to MERS-CoV infection. J Infect and Public Health. 2018;11(2):260-4. https://doi.org/10.1016/j.jiph.2017.08.006

11. Evans HL, Thomas CS, Bell LH, Hink AB, O'Driscoll S, Tobin CD, et al. Development of a sterile personal protective equipment donning and doffing procedure to protect surgical teams from SARS-CoV-2 Exposure during the COVID-19 Pandemic. Surg Infect. 2020;21(8). https://doi. org/10.1089/sur.2020.140

12. Mok E, Chung BP, Chung JW, Wong TK. An exploratory study of nurses suffering from severe acute respiratory syndrome (SARS). Int J Nurs Pract. 2005;11(4):150-60. https://doi.org/10.1111/j.1440-172X.2005.00520.x

13. Muñoz-Leyva F, Niazi AU. Common breaches in biosafety during donning and doffing of protective personal equipment used in the care of COVID-19 patients. Can J Anaesth. 2020;67(7):900-1. https://doi.org/10.1007/s12630-020-01648-x

14. Oliveira HC, Souza LC, Leite TC, Campos JF. Personal Protective Equipment in the coronavirus pandemic: training with Rapid Cycle Deliberate Practice. Rev Bras Enferm. 2020;73(suppl 2). https://doi.org/10.1590/0034-7167-2020-0303

15. The Lancet Editorial. COVID-19: protecting health-care workers. 2020;395(10228):P922. https://doi.org/10.1016/S0140-6736(20)30644-9

16. Arons MM, Hatfield KM, Reddy SC, Kimball A, James A, Jacobs JR, et al. Presymptomatic SARS-CoV-2 infections and transmission in a skilled nursing facility. N Engl J Med. 2020;382(22):2081-90. https://doi.org/10.1056/NEJMoa2008457

17. Rivett L, Sridhar S, Sparkes D, Routledge M, Jones NK, Forrest S, et al. Screening of healthcare workers for SARS-CoV-2 highlights the role of asymptomatic carriage in COVID-19 transmission. J Epidemiol Glob Health. 2020;9:e58728. https://doi.org/10.7554/eLife.58728 